\title{
ESTUDO DA SUSCETIBILIDADE À INUNDAÇÃO COM BASE EM ANÁLISE GEOMORFOLÓGICA, BACIA HIDROGRÁFICA DO ARROIO SANTA ISABEL, REGIÃO COSTEIRA DO RIO GRANDE DO SUL, BRASIL
}

Jonathan Duarte MARTH

Nina Simone Vilaverde MOURA

Edinei KOESTER

\begin{abstract}
RESUMO
As inundações causam prejuízos em todo o mundo, afetando principalmente a população que ocupa áreas próximas aos leitos dos rios. Considerando a diversidade de condicionantes das inundações, este estudo buscou o entendimento da inter-relação de fatores geomorfológicos, climatológicos e antrópicos para mapear e categorizar a suscetibilidade à inundação da bacia hidrográfica do arroio Santa Isabel, tributário do rio Camaquã, sul do Rio Grande do Sul, região com frequentes inundações. A análise dos mapas geológico, geomorfológico, hipsométrico, clinográfico, cobertura vegetal e usos da terra, com o apoio do levantamento de uma longa série histórica de pluviosidade (46 anos) e de imagens referentes aos períodos dos eventos de inundação captadas pelo sensor Landsat 5, permitiram categorizar cinco níveis de suscetibilidade à inundação na referida bacia. Os fatores determinantes para essa categorização foram: amplitude do relevo e declividade na planície de inundação e no seu entorno imediato e as intervenções antrópicas diretas e indiretas nessa planície, com destaque para supressão da vegetação e para as alterações nos canais (construção de barragens). Ainda foi considerada a influência exercida pelo rio Camaquã na porção jusante da bacia. A bacia apresenta suscetibilidade média a muito forte em $75 \%$ do sistema fluvial. A metodologia utiliza uma abordagem integrada de dados de fácil acesso e mostrou-se satisfatória à análise das inundações, servindo de base para o ordenamento territorial.
\end{abstract}

Palavras-chave: Suscetibilidade à inundação; mapeamento geomorfológico; sistema fluvial; arroio Santa Isabel.

\section{ABSTRACT}

FLOOD SUSCEPTIBILITY STUDY BASED ON GEOMORPHOLOGICAL ANALYSIS OF THE HYDROGRAPHIC BASIN OF ARROIO SANTA ISABEL, COASTAL REGION OF RIO GRANDE DO SUL, BRAZIL. Floods cause damage worldwide, affecting mainly the population who lives in areas near the rivers. Considering the diversity of flood conditions, this study aims to understand the interrelationship between geomorphological, climatological, and anthropic factors to map and classify flood susceptibility in the Arroio Santa Isabel basin, a tributary of the Camaquã River, south of Rio Grande do Sul, a region which is frequently stricken by floods. The analysis of geological, geomorphological, hypsometric, clinographic, vegetation and land use maps was based on historical series of rainfall data (46 years) and on images related to periods of flooding captured by the Landsat 5 sensor, making it possible to identify five levels of susceptibility to flooding in this basin. The determining factors for this classification were: amplitude of the relief, slope of the floodplain and its immediate surroundings, and direct and indirect anthropogenic interventions in this lowland, with emphasis on removal of vegetation and changes in the channels (dam construction). The influence exerted by the Camaquã River on the downstream part of the basin was also considered. In this basin, $75 \%$ of the fluvial system has moderate to 
very high susceptibility to flooding. The methodology uses an integrated approach of easy-access data and was successful in analyzing flooding, providing a foundation for territorial ordering.

Keywords: Susceptibility to flooding; geomorphological mapping; fluvial system; Santa Isabel stream.

\section{INTRODUÇÃO}

A ocorrência de inundações tem causado muitos prejuízos à população que habita as áreas próximas aos leitos dos rios. Os problemas resultantes dependem do grau de ocupação populacional e da frequência desses eventos (TUCCI 2002). Mais de 29 milhões de brasileiros residiam em áreas suscetíveis a inundações e em média 100 pessoas/ano eram vitimadas por estes desastres naturais (COLLINS 2004).

No sul do Rio Grande do Sul, na interface entre o Planalto Uruguaio Sul-rio-grandense e a Planície e Terras Baixas Costeiras, há um grande número de rios que, anualmente, estão sujeitos a inundações. TELLES (2002) identificou este problema nos municípios de Cerrito e Pedro Osório, onde são recorrentes as inundações do rio Piratini que causam prejuízos à população tanto de áreas urbanas, quanto rurais. A autora relatou três inundações excepcionais que ocorreram nos anos de 1959, 1983 e 1992, quando o nível da lâmina d'água atingiu mais de $17 \mathrm{~m}$, inundando cerca de $80 \%$ da área urbana, destruindo pontes, estradas, lavouras e olarias.

Este trabalho apresenta um método analítico para mapear e categorizar a suscetibilidade à inundação da bacia hidrográfica arroio Santa Isabel, tributário do rio Camaquã, a partir da inter-relação de fatores geomorfológicos, climatológicos e antrópicos. O termo suscetibilidade pode ser conceituado como a possibilidade de ocorrência de um determinado evento (SANTOS 2012). Este evento pode ser qualificado como um fenômeno relacionado a perdas e danos a sociedade. O mapeamento da suscetibilidade depende das características naturais intrínsecas da área de estudo.

A área de estudo situa-se no sul do Rio Grande do Sul, nos municípios de São Lourenço do Sul (distritos de Prado Novo e Boqueirão) e Cristal (distrito Passo do Mendonça), entre as latitudes $31^{\circ} 3^{\prime} 49,5^{\prime}$ ' S - 31 1 16'19,29" S e longitudes $51^{\circ} 48^{\prime} 33,76^{\prime \prime} \mathrm{W}-52^{\circ} 8^{\prime} 34,70^{\prime \prime} \mathrm{W}$ (Figura 1). O arroio Santa Isabel deságua próximo à foz do rio Camaquã, importante rio do estado do Rio Grande do Sul. Sua bacia abrange uma área de cerca de $295 \mathrm{~km}^{2}$, integralmente em zona rural, e situa-se a aproximadamente $150 \mathrm{~km}$ da capital do estado (Porto Alegre) e 100 km do município de Pelotas.

\section{PRESSUPOSTOS TEÓRICOS E CONCEITUAIS}

Inundações e enchentes são fenômenos naturais de caráter hidrometeorológico ou hidrológico, que ocorrem no sistema fluvial. Estes termos, apesar de utilizados como sinônimos, são conceitos diferentes. A inundação representa o transbordamento das águas de um corpo d'água, que atinge a planície de inundação ou várzea, enquanto a enchente consiste na elevação do nível d'água do canal de drenagem devido ao aumento da vazão, atingindo a cota máxima do canal, sem haver extravasamento (AMARAL \& RIBEIRO 2009).

O conceito de inundação está relacionado ao extravasamento das águas do leito menor de um rio para a planície de inundação (CASTRO 1998). Isto ocorre quando a quantidade de água que chega simultaneamente ao rio é superior à sua capacidade de drenagem. A magnitude e a frequência das inundações se dão em função da intensidade e distribuição da precipitação na bacia, da taxa de infiltração de água e grau de saturação no solo e das características morfométricas e morfológicas da bacia de drenagem (AMARAL \& RIBEIRO 2009).

$\mathrm{O}$ termo inundação também se diferencia do que se denomina enxurrada, pois esta última refere-se ao volume de água que escoa na superfície do terreno com grande velocidade, devido a eventos chuvosos intensos (CASTRO 1998). Esse tipo de evento tem forte relação com os processos que ocorrem no setor de vertentes, podendo ou não estar associado ao domínio dos processos fluviais.

Os fatores condicionantes de inundações e enchentes são de origem natural e/ou antrópica (SOUZA 1998). Os condicionantes naturais se dividem em: climático-meteorológicos (magnitude e frequência de chuvas), geológico-geomorfológicos (substrato geológico, morfometria da bacia de drenagem, solo e cobertura vegetal), flúvio-hidrológicos (hidráulica fluvial, correntes geradas por marés em áreas estuarianas e lagunares) e oceanográficos (influência das marés e da dinâmica de circulação costeira junto à desembocadura fluvial ou lagunar). 

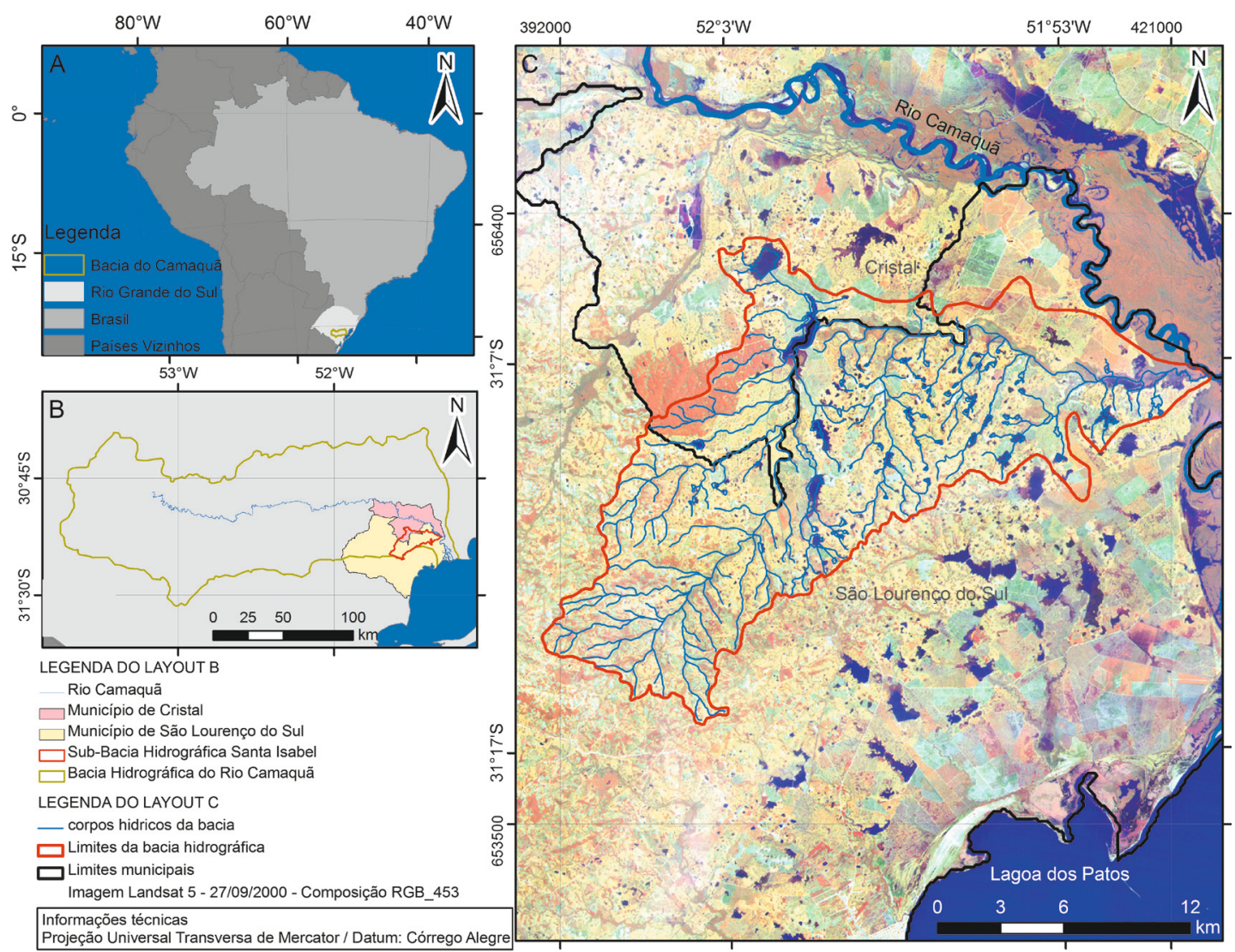

FIGURA 1 - Localização da bacia hidrográfica arroio Santa Isabel na (A) América do Sul, (B) Bacia Hidrográfica do Rio Camaquã e (C) nos municípios de Cristal e São Lourenço do Sul/RS.

Por outro lado, os condicionantes antrópicos resultam de intervenções diretas ou indiretas nas bacias, tais como: uso e ocupação de áreas marginais aos canais de drenagem que alteram a cobertura do solo e influenciam na capacidade de infiltração da água e no escoamento superficial, modificações na rede de drenagem (aterros, construção de estruturas lineares e barragens, entre outros) e modificações na sedimentação e no balanço sedimentar do sistema costeiro associado à bacia hidrográfica.

Para COOKE \& DOORNKAMP (1990) os fatores que se interrelacionam e são responsáveis pela ocorrência de eventos de inundação podem ser divididos em transitórios, permanentes e mistos. Os fatores transitórios estão associados às chuvas, à evapotranspiração e ao grau de saturação do solo. Os fatores permanentes correspondem às características morfométricas da bacia de drenagem e ao substrato rochoso, enquanto os fatores mistos estão relacionados ao tipo de uso e ocupação do solo.

Existem dois tipos de eventos pluviométricos distintos que podem resultar em diferentes situações de inundação em uma bacia hidrográ- fica: os eventos acumulados e os extremos. Os eventos acumulados correspondem à soma do total precipitado em diferentes eventos de chuva, fato que favorece a saturação do solo e o incremento do escoamento superficial, que pode exceder a capacidade de vazão dos corpos hídricos da bacia. Os eventos extremos, considerados neste estudo, consistem em precipitações intensas no período de $24 \mathrm{~h}$. Na literatura, usam-se comumente as médias climatológicas para definição deste tipo de evento. Essas técnicas possuem capacidade de identificar eventos de rara ocorrência, principal característica desses eventos.

LIEBMANN et al. (2001) estabeleceram limiares correspondentes a percentuais de médias climatológicas anuais e sazonais para definir eventos extremos no estado de São Paulo; neste caso, os limiares corresponderam a $20 \%$ do total climatológico sazonal. Já CALVETTI et al. (2006) consideram eventos extremos as precipitações acima de $50 \mathrm{~mm} / 24 \mathrm{~h}$.

As características morfométricas de uma bacia exercem forte influência sobre a suscetibilida- 
de à inundação. SOUZA (2005) concluiu que os parâmetros morfométricos que apresentam maior relação com o desencadeamento potencial das inundações são: hierarquia da bacia, número e frequência de canais totais e de primeira ordem, área da bacia, comprimento do canal principal, forma da bacia, fator forma e índice de circularidade, declividade do canal principal e da bacia, densidade de drenagem e densidade hidrográfica (relação entre número de cursos d'água e área da bacia), densidade de confluências e relação de bifurcação, taxa de relevo (relação entre amplitude altimétrica e comprimento máximo da bacia) e rugosidade. MORISAWA (1962) considerou que a descarga e o escoamento superficial são função principalmente da área da bacia, do comprimento total dos canais, da frequência dos canais de $1^{\mathrm{a}}$ ordem, do gradiente ou declividade do canal principal e da circularidade da bacia.

\section{MATERIAIS E MÉTODOS}

A delimitação da bacia foi realizada a partir de cartas topográficas editadas pelo Ministério do Exército, Diretoria de Serviço Geográfico, escala 1:50.000. As informações geomorfológica e climática regionais basearam-se, respectivamente, nos trabalhos de IBGE $(1986,2003)$ e EMBRAPA (2006). O Mapa Geológico do Rio Grande do Sul, escala 1:250.000, Folha Pelotas (CPRM 2003) forneceu informações sobre os condicionantes estruturais e permitiu interpretações sobre a morfogênese, dando suporte ao mapa geomorfológico.

O mapeamento geomorfológico contemplou o terceiro nível taxonômico da proposta de ROSS (1992) e consistiu na fotointerpretação das formas de relevo em fotografias aéreas em escala 1:60.000 (Projeto AF.63.32 de 1964 e 1965), com ênfase na delimitação da planície de inundação (planície fluvial) e na separação dos modelados correspondentes aos processos de acumulação e dissecação. As formas com especial interesse no mapeamento foram os terraços (lagunar e coluvio-aluvionar) e as rampas coluvio-aluvionares. Produtos auxiliares - mapas hipsométrico e clinográfico da bacia - foram gerados a partir do modelo digital de terreno do Shuttle Radar Topography Mission (SRTM), com resolução espacial de $90 \mathrm{~m}$, disponibilizado pela EMBRAPA (MIRANDA 2005). Estes produtos auxiliaram na interpretação geomorfológica e na compartimentação da planície de inundação da bacia hidrográfica.

Com intuito de caracterizar os condicionantes climático-meteorológicos compilaram-se os da- dos de precipitação no período de 1966 a 2011 da estação pluviométrica Boqueirão, localizada próxima das nascentes da bacia, disponibilizados no site da Agência Nacional de Águas. Apesar de haver outras estações pluviométricas na região, estas não possuem os dados de precipitação em alguns períodos da série histórica adotada, por isto optou-se por utilizar somente uma, devido a consistência dos dados. Os dados foram manipulados no software Hidro 1.2.1., sendo extraída a média das precipitações e, com base nos totais diários destas, foram identificados volumes pluviométricos que pudessem causar inundações. O limiar pluviométrico capaz de causar inundações na bacia baseou-se na proposta de CALVETTI et al. (2006), que consideraram eventos extremos as precipitações acima de $50 \mathrm{~mm} / 24 \mathrm{~h}$. Estes autores aplicaram metodologia baseada na frequência das precipitações para analisar a probabilidade de ocorrência destas em nove sub-bacias do rio Iguaçu, no estado do Paraná.

Com o intuito de se entender a influência dos fatores antrópicos na deflagração dos processos de inundação, elaborou-se, a partir da análise de composição colorida (R4G5B3 - falsa cor) de imagem Landsat 5 de 2010, sensor TM (Thematic Mapper), um mapa de usos da terra e de cobertura vegetal, com seis classes (IBGE 2006): águas, matas nativas, silvicultura, campos-pastagens, lavouras e solos expostos. Para esse fim, utilizou-se o método de classificação supervisionada da distância mínima. Este mapeamento foi complementado com o levantamento de dados referentes aos tipos de cultivos e criações dos municípios de Cristal e São Lourenço do Sul, junto ao Sistema IBGE de Recuperação Automática - SIDRA, dos anos 1995 e 2010. Isso permitiu avaliar temporalmente as variações da área utilizada para os principais plantios e criações.

A elaboração do mapa de suscetibilidade considerou os condicionantes climático-meteorológicos, morfométricos e antrópicos, porém não se tratou de uma análise quantitativa, não havendo uma atribuição de peso para as variáveis, mas sim uma interpretação geomorfológica da inter-relação destas. Os fatores determinantes para a categorização de suscetibilidade foram: amplitude do relevo e declividade na planície de inundação e no seu entorno imediato e as intervenções antrópicas diretas e indiretas nessa planície, com destaque para supressão da vegetação e para alterações nos canais (construção de barragens).

Contudo, por não haver dados disponíveis comumente utilizados em estudos de inundações, tais como vazão, medidas do nível d'água, entre outros, buscou-se relacionar os dados de precipitação com 
a ocorrência de eventos de inundação registradas em imagens de satélite. Dessa forma, foram compiladas todas as imagens Landsat 5 disponíveis para a área no período da série histórica (1966 a 2011), sendo selecionadas 12 imagens, que foram analisadas na composição colorida (R4G5B3 - falsa cor). Contudo, entre essas, somente três imagens apresentaram aumento da lâmina d'água, permitindo, assim, associar a dimensão das inundações com os totais precipitados. Os valores de precipitação referem-se a eventos acumulados de chuvas e a eventos extremos em $24 \mathrm{~h}$, como já referido anteriormente.

Foram realizados três trabalhos de campo, visando ajustar o mapa geomorfológico, a partir de vistoria nos limites da planície de inundação com os terraços encontrados na área, confirmar as classes mapeadas de cobertura vegetal e usos da terra e interpretar os fatores e condicionantes locais do mapa de suscetibilidade à inundação. Também se fez registro das principais feições do relevo e das áreas correspondentes às diferentes classes de suscetibilidade.

\section{CARACTERIZAÇÃO DOS CONDICIONANTES CLIMÁTICO- METEOROLÓGICOS}

O clima da área de estudo sofre influências da movimentação e do encontro de massas de ar polares e tropicais (CARGNIN et al. 2002). Cabe destacar ainda que o fenômeno El Niño também influencia o clima da região, aumentando a temperatura média e ocasionando precipitações abundantes. No período de outubro a dezembro, há uma probabilidade de mais de $80 \%$ dos eventos El Niño determinarem precipitações acima da média climatológica (BERLATO \& FONTANA 2003).

$\mathrm{Na}$ série histórica das precipitações, os meses mais chuvosos na bacia são fevereiro, julho e setembro, enquanto os menos chuvosos, abril e novembro (Figura 2). Os anos de 1968 e 1998 apresentaram, respectivamente, a menor $(1003,9 \mathrm{~mm})$ e a maior precipitação $(2210,3 \mathrm{~mm})$ anual da série analisada (Figuras 3 e 4).

CALVETTI et al. (2006), utilizando métodos de análise de frequência e impacto hidrológico por meio de simulações com modelo chuva-vazão, indicaram valores diários acima de $50 \mathrm{~mm}$ como eventos extremos. $\mathrm{Na}$ área de estudo foram registrados 253 dias com precipitações acima deste valor na série histórica, sinalizando um grande número de dias com eventos extremos.

Também foram averiguadas as chuvas acumuladas, que consistem em precipitações ocor-

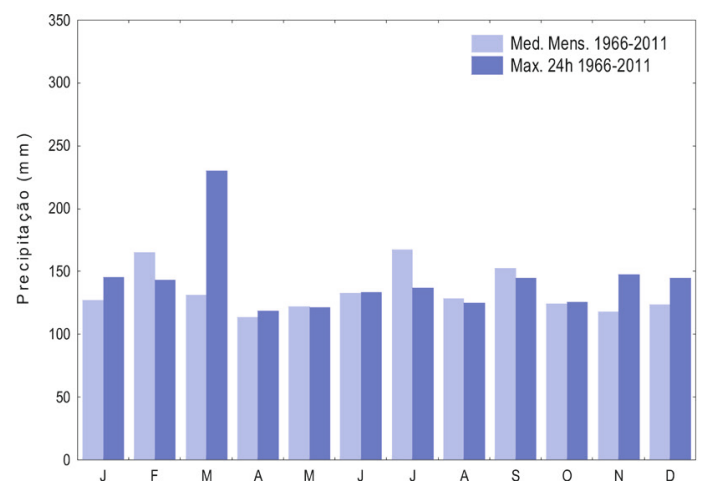

FIGURA 2 - Média dos totais mensais e máximos diários de precipitação em cada mês da série histórica da bacia hidrográfica arroio Santa Isabel (1966-2011).

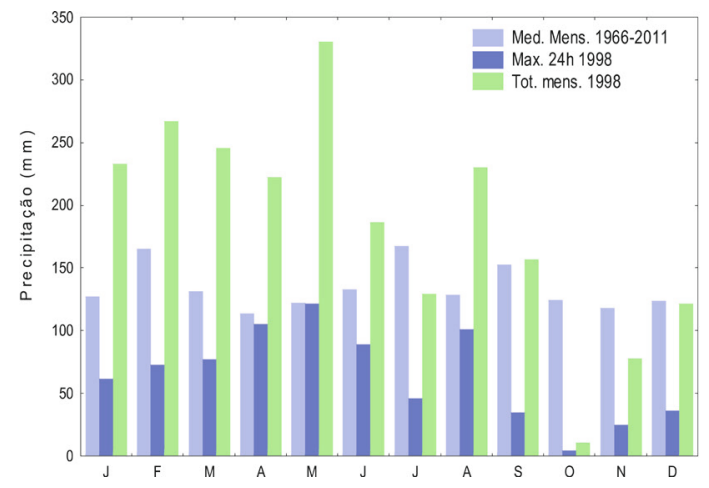

FIGURA 3 - Precipitação total mensal e máxima diária em cada mês do ano de 1998 comparados a média da série histórica (1966-2011) na bacia hidrográfica arroio Santa Isabel.

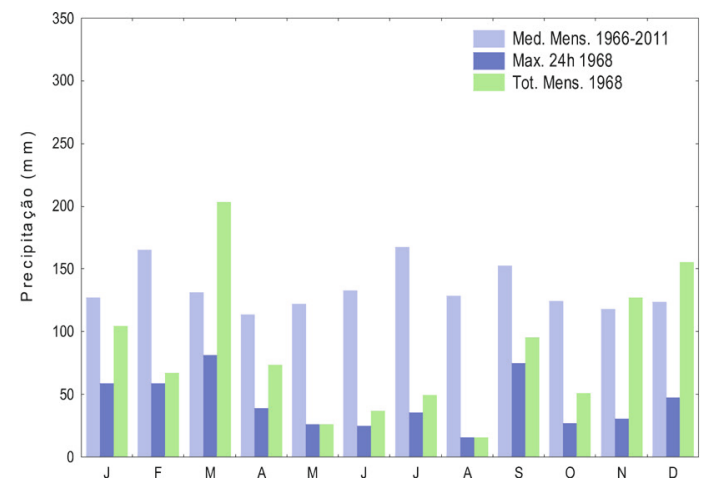

FIGURA 4 - Precipitação total mensal e máxima diária em cada mês do ano de 1968 comparados a média da série histórica (1966-2011) na bacia hidrográfica arroio Santa Isabel. 
ridas em uma sequência de eventos de chuva no período de 2 dias ou mais. No período houve 166 eventos de chuvas acumuladas, sendo que o mês de maior ocorrência foi julho, com 25 eventos. Considerando-se os eventos de chuvas acumuladas em 46 anos de registros pluviométricos, percebe-se que há, em média, quase quatro eventos por ano capazes de provocar inundações, sugerindo que a área possui potencial climático-meteorológico para tais processos.
TABELA 1 - Dias de chuva e precipitação total no período que antecedeu a data de aquisição das imagens Landsat (Figura 5) selecionadas da bacia hidrográfica arroio Santa Isabel.

\begin{tabular}{ccc}
\hline Imagens utilizadas & $\begin{array}{c}\text { Dias de } \\
\text { chuva }\end{array}$ & $\begin{array}{c}\text { Precipitação } \\
\text { total }(\mathrm{mm})\end{array}$ \\
\hline Imagem Landsat de 01/06/1986 & 3 & 147,8 \\
Imagem Landsat de 27/09/2000 & 6 & 118,5 \\
Imagem Landsat de 23/03/2007 & 3 & 182,7 \\
\hline
\end{tabular}
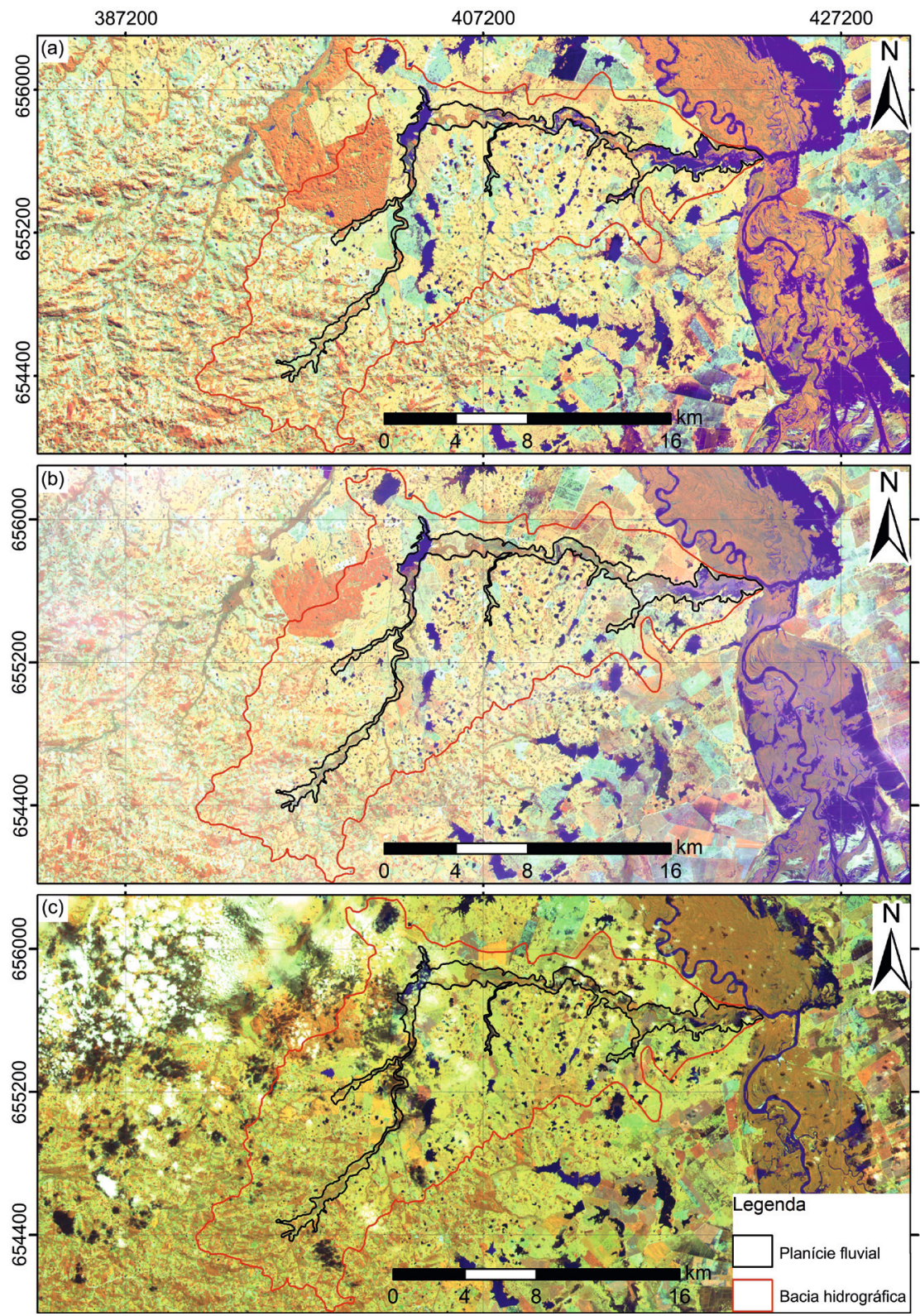

FIGURA 5 - Imagens Landsat com registro de inundações na bacia hidrográfica arroio Santa Isabel: a) 1986, b) 2000 e c) 2007. 
Os períodos de inundação na bacia (Tabela 1) estão registrados nas três imagens de satélite selecionadas (Figura 5), permitindo mapear as áreas inundáveis na planície de inundação pelos diferentes níveis de eventos observados.

\section{CARACTERIZAÇÃO DOS CONDICIONANTES GEOLÓGICO- GEOMORFOLÓGICOS}

$\mathrm{Na}$ bacia foram identificadas seis unidades geológicas (Figura 6), sendo três delas constituídas por rochas graníticas da morfoestrutura Cráton Rio de La Plata e Cinturão Dom Feliciano (Neoproterozóico) e as demais associadas a depósitos sedimentares do Quaternário e Terciário da morfoestrutura Bacia de Pelotas. Nas áreas de rochas graníticas verificou-se que a assimetria dos vales exerce influência local na dinâmica hidrológica da planície de inundação do arroio Santa Isabel. Percebe-se também que os fatores estruturais que mais influenciam nessa dinâmica são as rupturas de declive na transição do planalto para a planície, que alteram o escoamento dos canais nestes locais, pois deixam de ter competência para escoar com facilidade o volume de água proveniente das encostas durante os eventos de precipitação intensa; o predomínio de superfícies planas e mal drenadas nas áreas sedimentares propicia a dispersão das águas que transbordam do leito menor no trecho à jusante da bacia hidrográfica.

O relevo da bacia tem amplitude de $201 \mathrm{~m}$ (Figura 7); as áreas mais elevadas situam-se no setor sudoeste, ao passo que as mais baixas estão próximas a foz do canal principal no setor leste. A geometria dos vales e, por consequência, a morfologia da planície de inundação varia ao longo da bacia, conforme pode ser observado nos perfis topográficos apresentados na figura 7. Nas áreas correspondentes ao Planalto Uruguaio Sul-rio-grandense as drenagens estão mais encaixadas, como se pode observar no perfil $\mathrm{A}-\mathrm{A}^{\prime}$, que corresponde às cabeceiras de drenagem da bacia. No perfil B - B' a dimensão interfluvial é maior, correspondendo à transição do planalto para os depósitos colúvioaluviais adjacentes, muito embora a amplitude altimétrica das vertentes em ambas as margens ainda permaneça elevada em relação ao fundo do vale. Nos perfis C - C' e D - D' observa-se uma assimetria entre as margens direita e esquerda, que deixa

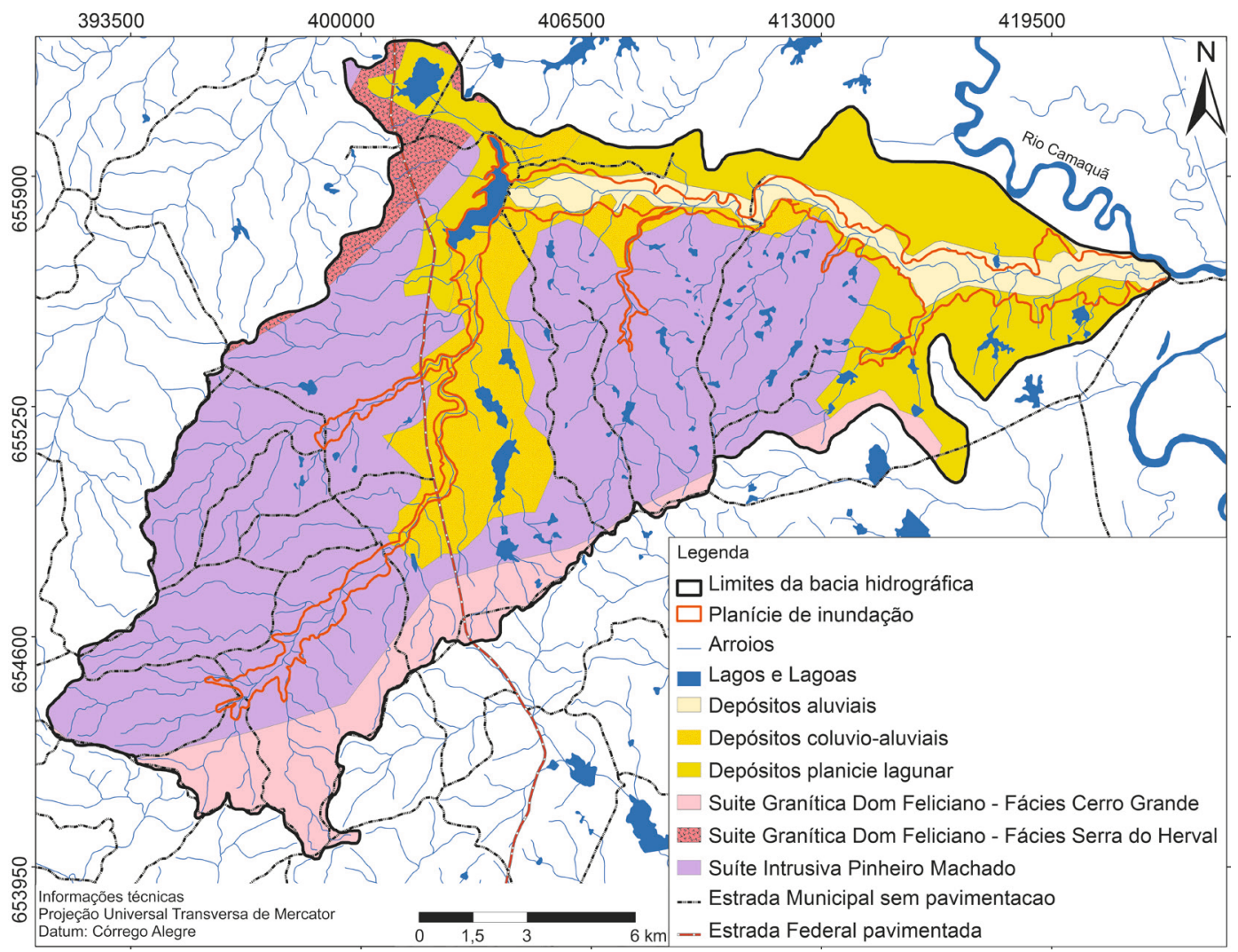

FIGURA 6 - Mapa geológico regional da bacia hidrográfica arroio Santa Isabel. Fonte: CPRM (2003). 

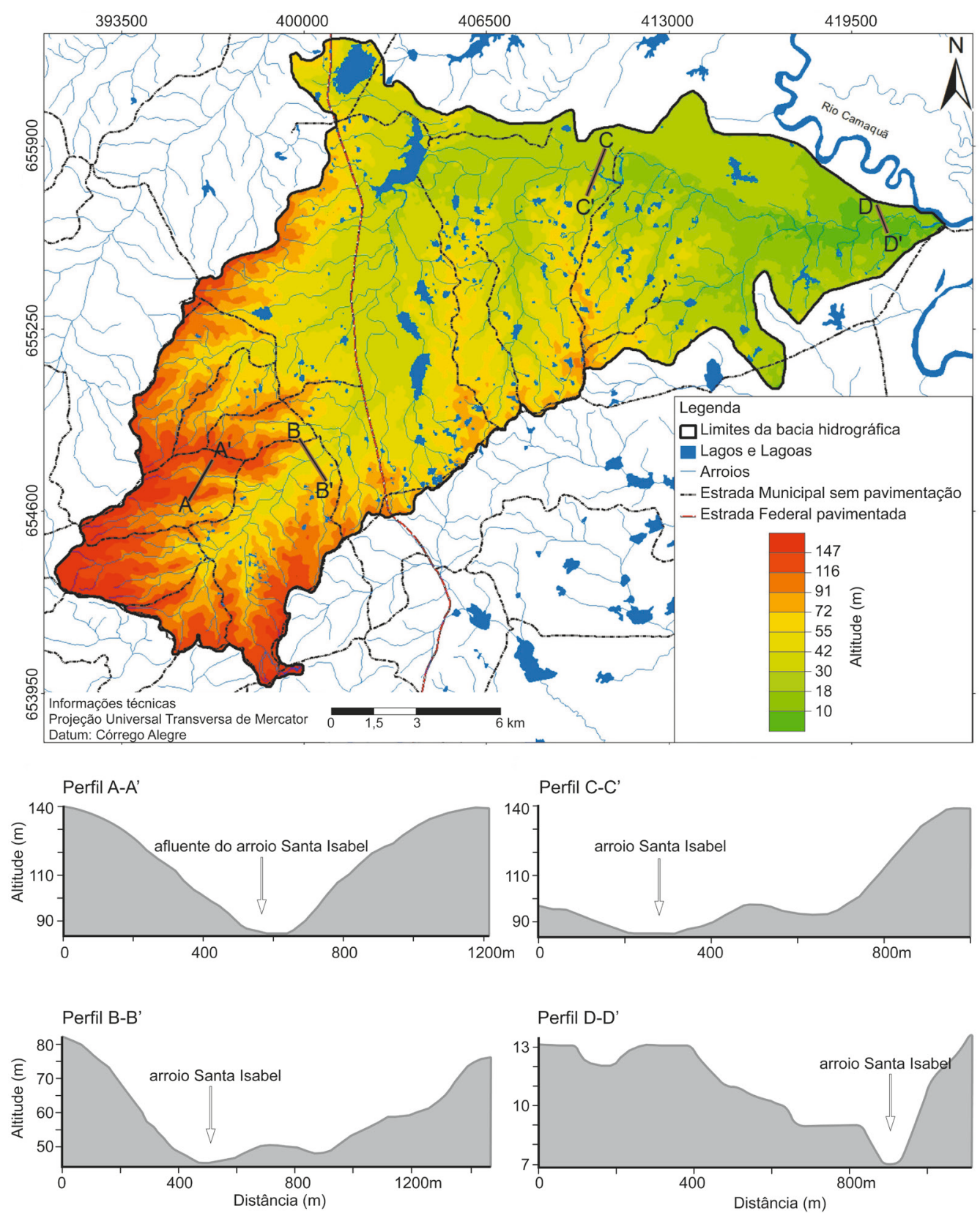

FIGURA 7 - Mapa hipsométrico da bacia hidrográfica arroio Santa Isabel.

as margens suavizadas mais suscetíveis durante os eventos de inundação. A análise das fotografias aéreas, imagens de satélite e os trabalhos de campo mostraram que o leito do arroio Santa Isabel divaga entre as margens esquerda e direita, assumindo um padrão meandrante no baixo curso, onde a planície de inundação é mais ampla.

As declividades predominantes são menores que $6 \%$ (Figura 8), contudo, no setor sudoeste predominam declividades acima de $6 \%$, excedendo os $30 \%$ nas cabeceiras de drenagem.
A bacia, em sua maior parte, é constituída por colinas e terraços (colúvio-aluvionares e lagunar) (Figura 9). Os terraços colúvio-aluvionares são compostos por sedimentos provenientes do planalto, que foram retrabalhados desde o Terciário. Seu trecho maior possui uma variação altimétrica de 50 $\mathrm{m}$ junto às colinas a $30 \mathrm{~m}$ nas proximidades da planície de inundação. O terraço lagunar é composto por depósitos pleistocênicos do sistema lagunabarreira, sendo sua superfície pouco ondulada a plana, com altitudes que variam de $50 \mathrm{~m}$ no noro- 


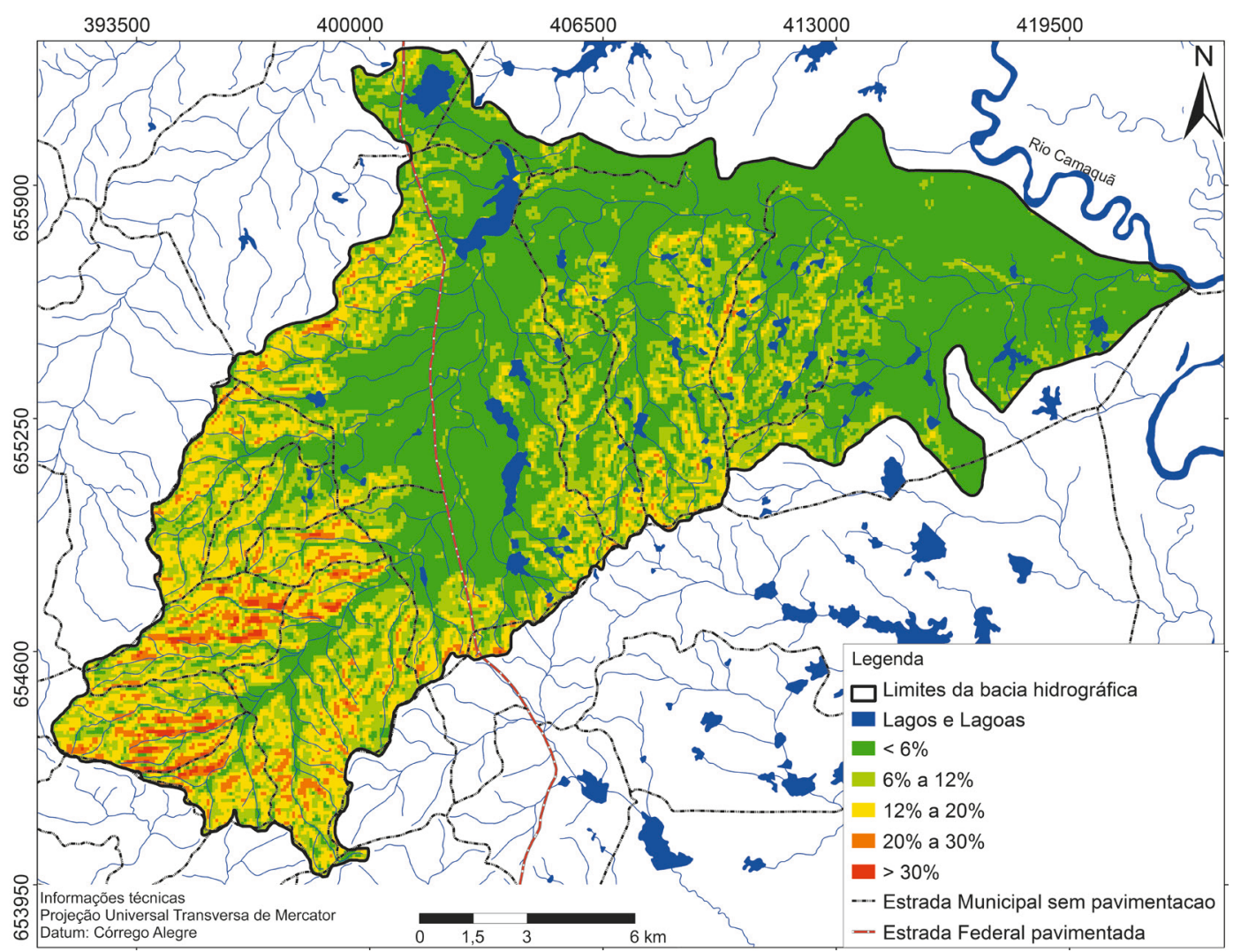

FIGURA 8 - Mapa de declividade da bacia hidrográfica arroio Santa Isabel.

este a $12 \mathrm{~m}$, próximo a foz do arroio Santa Isabel. As declividades desta unidade estão abaixo de 6\% e mesmo com a baixa amplitude altimétrica, ela constitui o divisor de águas da bacia hidrográfica do arroio Santa Isabel em todo o setor norte. Este terraço também circunda a planície de inundação do arroio Santa Isabel, havendo uma ruptura de relevo de aproximadamente $5 \mathrm{~m}$ entre eles.

O mapeamento geomorfológico permitiu a identificação de oito unidades de relevo na bacia do arroio Santa Isabel (Figura 10).

\section{USO E OCUPAÇÃO DA TERRA E COBERTURAL VEGETAL}

O mapeamento do uso da terra e da cobertura vegetal (Figura 11, Tabela 2) revelam o predomínio de lavouras temporárias, com destaque para arroz, milho, fumo, soja, e grandes rebanhos (aproximadamente $70 \%$ ), em detrimento da mata nativa. Nos últimos anos a vegetação nativa, que corresponde à Floresta Estacional Semidecidual (submontana $\mathrm{e}$ aluvial), tem se mantido estável, mas se restringe praticamente às margens dos arroios. A cultura do fumo é a que mais cresceu proporcionalmente nos municípios de Cristal e São Lourenço do Sul no período analisado (1995-2010), enquanto o plantio de arroz representa a maior área de plantio. Cabe destacar o grande número de represas ao longo da bacia, que interferem direta e indiretamente no sistema fluvial, alterando a capacidade de vazão dos canais e o nível da lâmina d'água em alguns trechos.

TABELA 2 - Classes de usos da terra e cobertura vegetal da bacia hidrográfica arroio Santa Isabel - 2010.

\begin{tabular}{ccc}
$\begin{array}{c}\text { Classe de uso } \\
\text { da terra }\end{array}$ & $\begin{array}{c}\text { Área } \\
\left(\mathrm{km}^{2}\right)\end{array}$ & $\begin{array}{c}\text { Percentagem } \\
(\%)\end{array}$ \\
\hline Água & 14,04 & 4,77 \\
Mata Nativa & 40,12 & 13,63 \\
Silvicultura & 14,57 & 4,95 \\
Lavouras & 17,92 & 6,09 \\
Campos Pastagens & 152,31 & 51,76 \\
Solos Expostos & 54,60 & 18,55 \\
Não Classificada & 0,70 & 0,25 \\
\hline Total & 294,25 & 100 \\
\hline
\end{tabular}


A

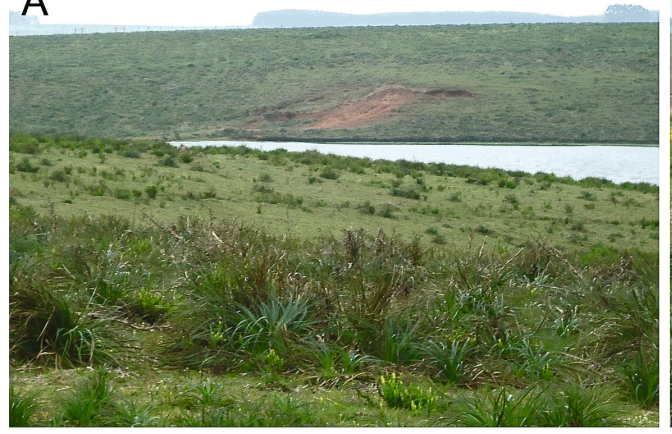

C
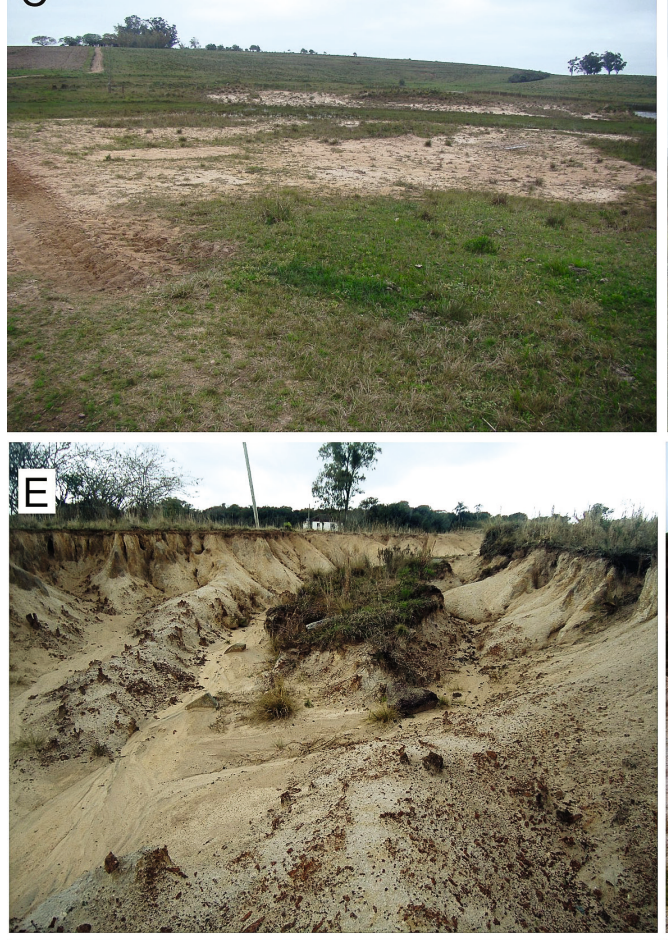

G

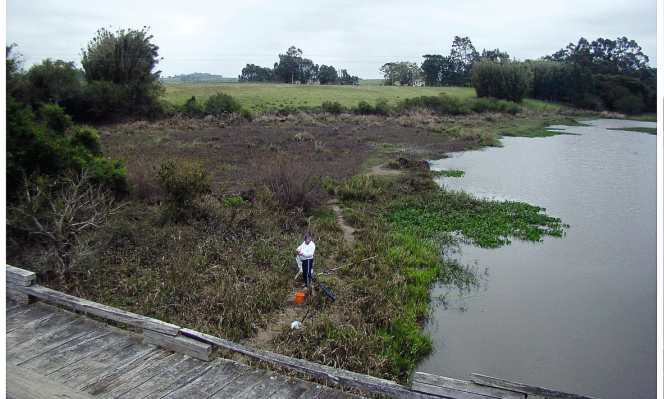

B

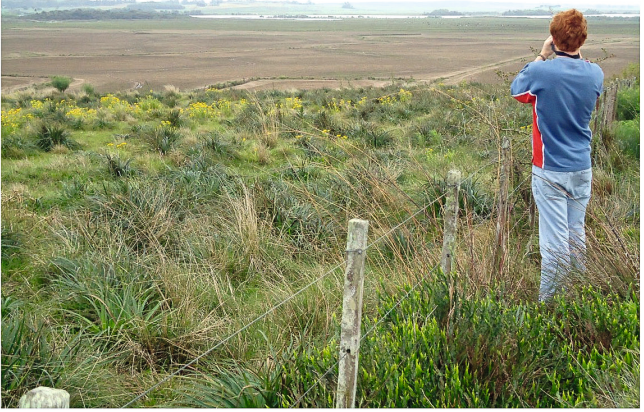

D
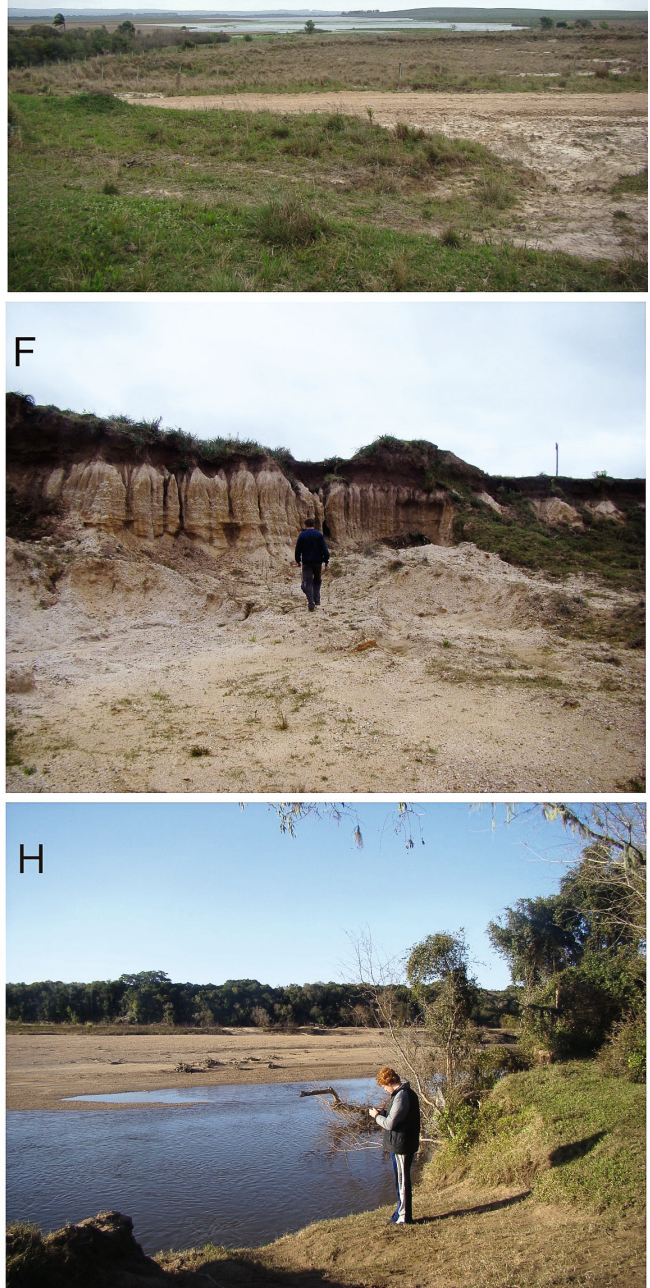

FIGURA 9 - Registro de unidades de relevo na bacia hidrográfica: A) Vale encaixado próximo as cabeceiras da bacia, B) Vista de terraço colúvio-aluvionar a partir de relevo colinoso, C) Contato entre terraço lagunar e colinas, D) Terraço lagunar próximo a barragem do arroio Santa Isabel, E) processos erosivos a jusante da barragem do arroio Santa Isabel, F) Ruptura de declive entre terraço lagunar e planície de inundação, G) área rebaixada associada ao arroio Santa Isabel e H) Rio Camaquã junto a foz da bacia. 


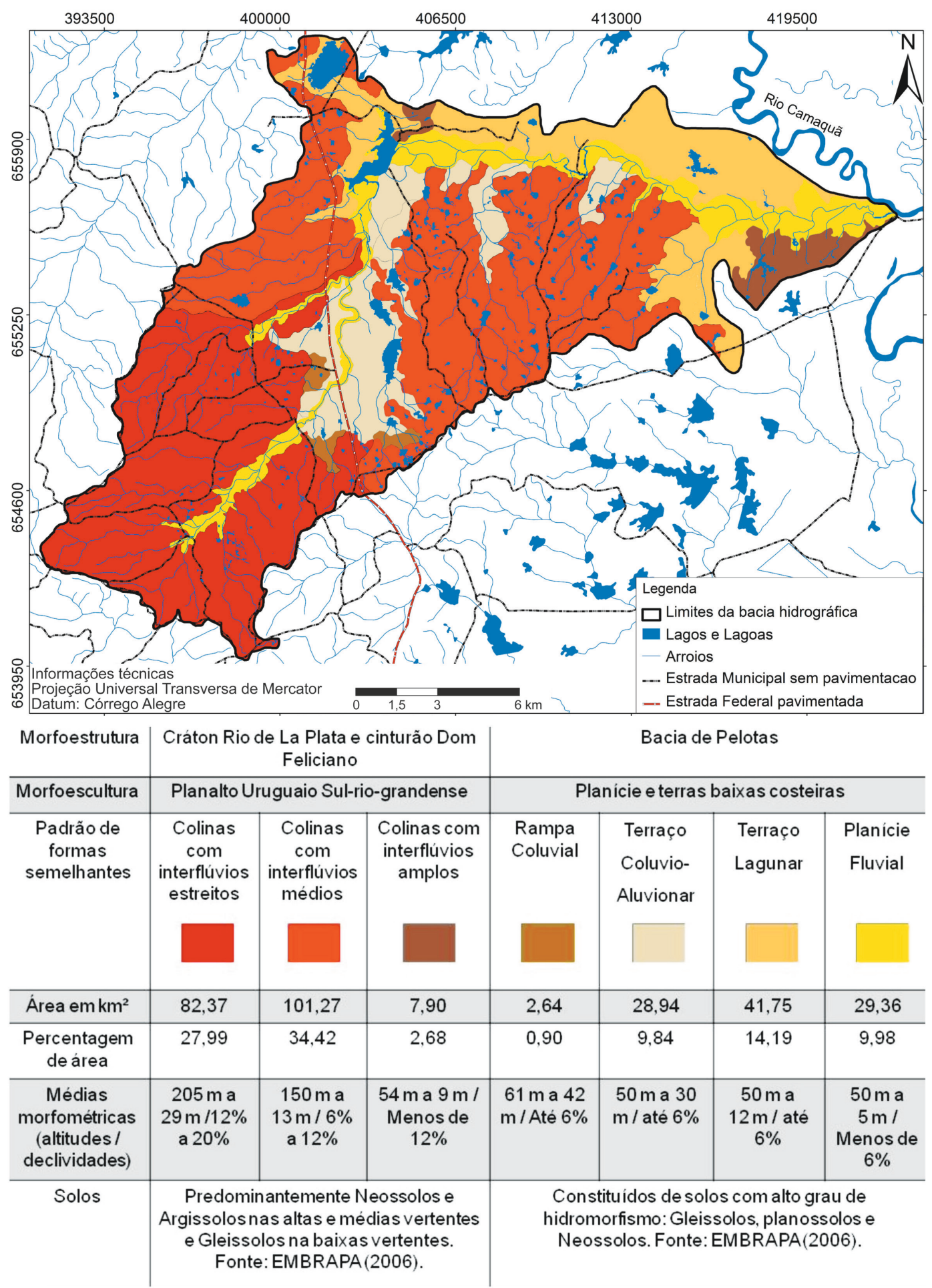

FIGURA 10 - Mapa das unidades de relevo da bacia hidrográfica arroio Santa Isabel. 


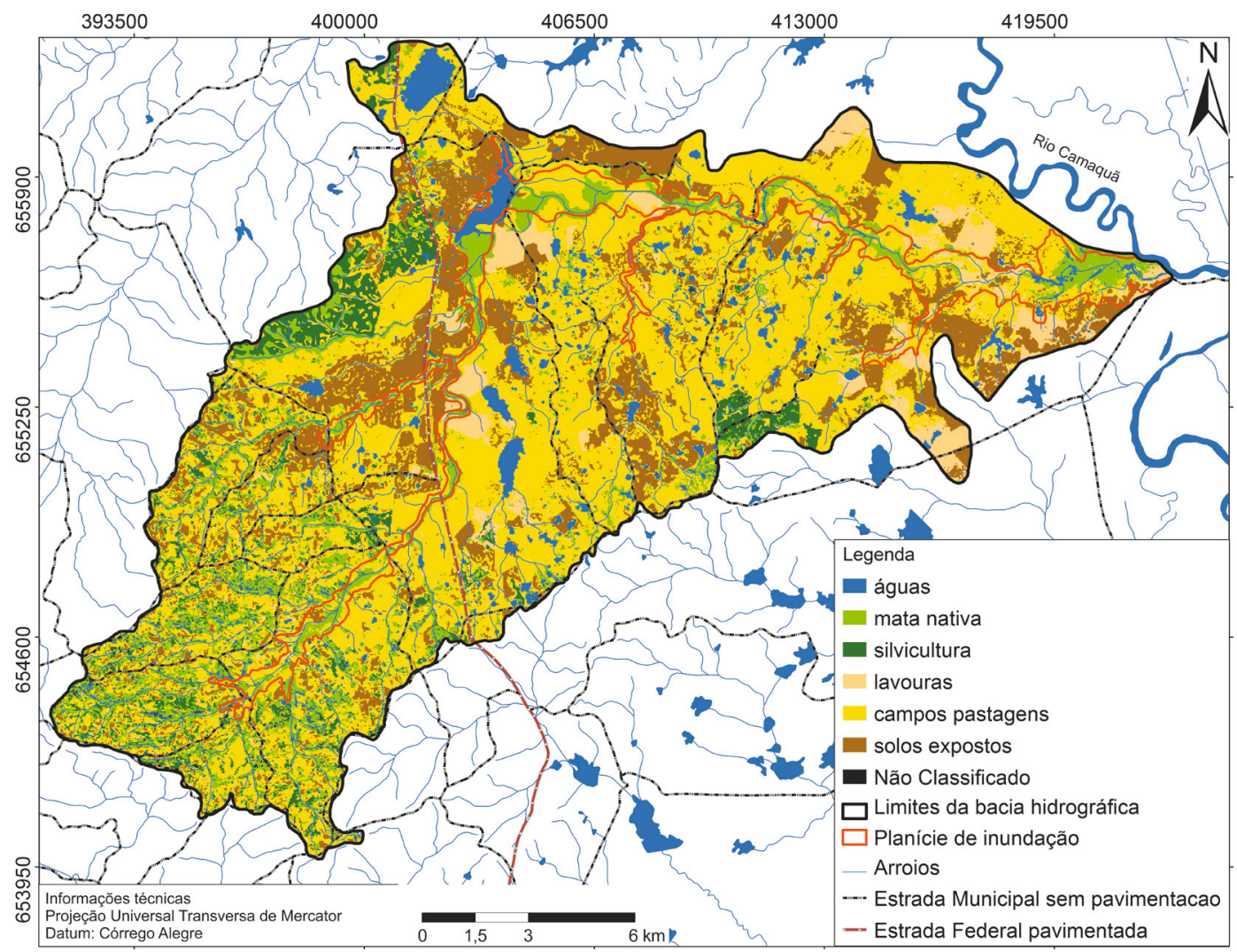

FIGURA 11 - Mapa de usos da terra e cobertura vegetal da bacia hidrográfica arroio Santa Isabel - 2010.

Na Planície de Terras Baixas, caracterizada pela divisão em grandes propriedades, há predomínio de plantio de arroz, soja e criação de gado. No Planalto Uruguaio Sul-rio-grandense há também pequenas propriedades com plantio de lavouras de milho, fumo e criação de frangos. A área utilizada para estas atividades alterou significativamente a cobertura vegetal e o sistema fluvial, haja vista sua expansão no decorrer do período analisado. Desta forma, áreas muito extensas com solo descoberto durante alguns períodos do ano, em função dessas culturas temporárias, facilitam o escoamento superficial. No mapa de usos da terra e cobertura vegetal é possível averiguar que as áreas com solos expostos estão concentradas principalmente nos terraços e nas áreas de colinas próximas da planície de inundação. Os trabalhos de campo permitiram confirmar que no entorno da planície de inundação há vários trechos sem vegetação.

\section{MAPEAMENTO E CARACTERIZAÇÃO DA SUSCETIBILIDADE A INUNDAÇÃO}

Os condicionantes geomorfológicos, como a amplitude do relevo e a declividade na bacia hi- drográfica, são os fatores com maior influência nas inundações da bacia. Estes resultados corroboram com os encontrados por SOUZA (2005), que propôs um método analítico utilizando parâmetros morfométricos no estudo de suscetibilidade à inundação de bacias hidrográficas na região costeira do estado de São Paulo. Por outro lado, os condicionantes antrópicos, associados principalmente à agricultura, foram responsáveis pela redução da cobertura vegetal no período de 1995 a 2010, diminuindo a retenção da água da chuva pela vegetação e favorecendo o escoamento superficial.

O grande número de barragens ao longo da bacia também contribuiu na intensificação das inundações, principalmente a montante dessas construções, devido ao controle da vazão nestas áreas. Isto foi observado nos trabalhos de campo, ao se constatar em áreas a montante das barragens, o aumento do nível da água, possivelmente em função dos depósitos de remanso e do assoreamento. O aumento da vazão do rio Camaquã provoca inundações na área próxima à foz do arroio Santa Isabel, em função do barramento da vazão deste. Resultado semelhante foi observado por LIMA 
(2010) ao estudar a relação entre o lago Guaíba e a bacia hidrográfica do arroio do Salso, que mostra a influência exercida pelo corpo hídrico de maior porte sobre aquele de menor porte.

A planície de inundação foi classificada em cinco níveis hierárquicos de suscetibilidade à inundação (Tabela 3, Figura 12), que variam de muito fraca a muito forte.

A classe de suscetibilidade muito fraca está associada a patamares da planície de inundação que se encontram próximos aos limites desta com os terraços lagunares adjacentes, predominantemente nas margens côncavas do arroio Santa Isabel. Estas áreas apresentam altitudes maiores que o restante da planície de inundação no seu entorno. Em alguns trechos o arroio Santa Isabel encontra-se encaixado, apresentando grande capacidade de vazão e, por consequência, uma suscetibilidade muito fraca a inundação. Há também uma área de suscetibilidade muito fraca na porção oeste da bacia, em um afluente da margem esquerda do arroio Santa Isabel. A declividade longitudinal alta deste arroio confere boa vazão neste segmento da planície de inundação. De maneira geral, estas áreas dificilmente são inundadas.

A área correspondente à classe de suscetibilidade fraca é a de menor abrangência na bacia e localiza-se no médio curso do arroio Santa Isabel, onde a planície de inundação encontra-se confinada pelos terraços colúvio-aluvionares (Figura 9C). A vegetação nativa no entorno do canal e a alta capacidade de vazão do arroio neste trecho, observada in loco (leito menor largo, encaixado nos terraços adjacentes e canal retilíneo), faz com que esta área seja inundada somente durante eventos de grande magnitude.

A classe de suscetibilidade média ocupa a maior extensão do sistema fluvial. Localiza-se no alto e médio curso do arroio Santa Isabel e ao longo de dois afluentes de sua margem direita.

No alto curso (porção sudoeste da bacia), a planície encontra-se topograficamente deprimida em relação às colinas, porém apresenta vegetação nativa nas margens do canal e ao longo de suas vertentes, além de grande variação longitudinal de altitude ao longo do canal. Estes fatores atenuam a situação de confinamento desta em relação às colinas adjacentes, propiciando vazão eficiente das águas oriundas de eventos de chuva e conferindo um caráter médio de suscetibilidade ao local.

No médio curso, esta unidade caracteriza-se por ser rebaixada em relação aos terraços colúvioaluvionares, porém sem desníveis altimétricos acentuados. Os canais de irrigação favorecem o escoamento das águas pluviais. Conforme observado nas imagens de satélite, essas áreas podem ser inundadas durante eventos acumulados.

Nos afluentes da margem direita do arroio Santa Isabel a inter-relação entre fatores potencializadores e atenuadores de inundação confere um caráter médio à suscetibilidade. Nos terraços lagunares e nas áreas de transição entre as colinas e os

TABELA 3 - Classificação da suscetibilidade à inundação no sistema fluvial da bacia hidrográfica arroio Santa Isabel.

\begin{tabular}{|c|c|c|c|}
\hline Suscetibilidade & Critérios & $\begin{array}{l}\text { Área } \\
\left(\mathrm{km}^{2}\right)\end{array}$ & $\begin{array}{l}\text { Percentagem } \\
(\%)\end{array}$ \\
\hline Muito fraca & $\begin{array}{l}\text { Localização marginal na planície de inundação, patamar levemente elevado em } \\
\text { relação ao restante da planície de inundação, em margens côncavas do canal. }\end{array}$ & 6,32 & 21,52 \\
\hline Fraca & Presença de vegetação nativa, características do canal (retilíneo, leito largo) & 1,30 & 4,43 \\
\hline Média & $\begin{array}{l}\text { Vertentes alongadas, que diminuem a velocidade do escoamento superficial, } \\
\text { ausência de vegetação nativa nas margens do canal, solos rasos e mal drenados, } \\
\text { influência dos canais de irrigação em alguns trechos }\end{array}$ & 10,44 & 35,56 \\
\hline Forte & $\begin{array}{l}\text { Ruptura de declive entre terraço lagunar e planície de inundação, } \\
\text { confluência de canais de } 2^{\mathrm{a}} \text { e } 3^{\mathrm{a}} \text { ordem }\end{array}$ & 3,93 & 13,39 \\
\hline Muito forte & $\begin{array}{l}\text { Menores altitudes da bacia hidrográfica, proximidade da foz da bacia, } \\
\text { influência do Rio Camaquã, trecho a montante de barragem influenciado pelo } \\
\text { assoreamento, retenção de vazão e mudanças de profundidade do canal. }\end{array}$ & 7,37 & 25,10 \\
\hline
\end{tabular}




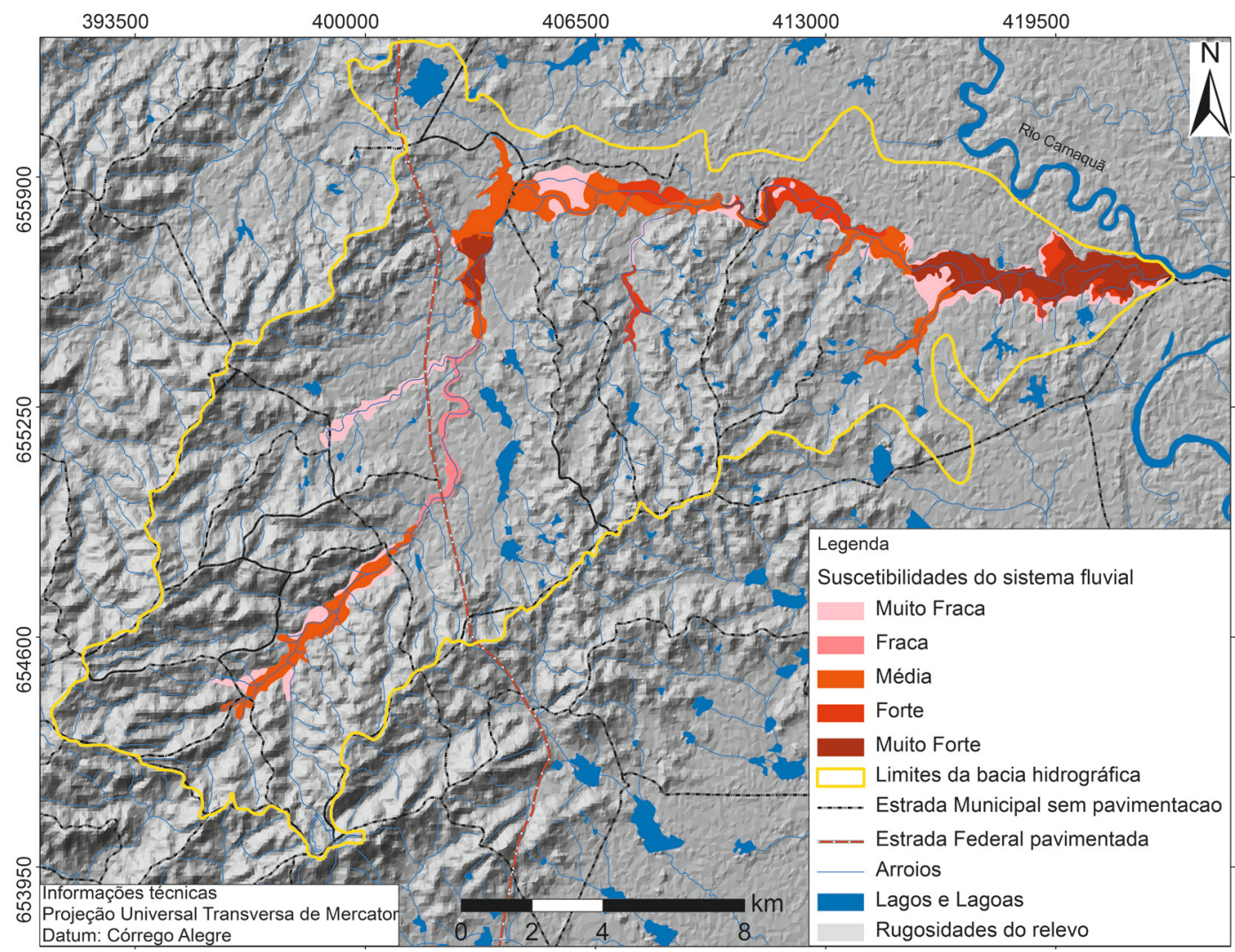

FIGURA 12 - Mapa de suscetibilidade do sistema fluvial da bacia hidrográfica arroio Santa Isabel.

terraços os solos são rasos, com baixa capacidade de drenagem e a vegetação não está presente no entorno dos canais; em contraposição, as vertentes são suavizadas e mais extensas, o que desacelera o escoamento superficial durante eventos de precipitação. Desta forma, nem mesmo eventos acumulados são capazes de provocar inundações nestes setores da bacia, haja vista que somente em uma das imagens esta área encontra-se inundada.

A classe de suscetibilidade forte consiste principalmente em áreas confinadas por terraço lagunar adjacente à planície de inundação do arroio Santa Isabel. Essas áreas encontram-se a jusante da maior barragem existente no arroio Santa Isabel; os eventos de inundação nesses locais podem ser visualizados em duas das três imagens de satélite (Figura 5). A barragem reativou o nível de base local e aumentou os processos erosivos nos terraços lagunares (Figura 9E), expandindo a planície de inundação. Também pertence à classe de forte suscetibilidade um trecho de um afluente da margem direita do arroio Santa Isabel, situado sobre sedimentos colúvio-aluvionares, associado a solos mal drenados (Gleissolos). Neste trecho há ainda a confluência de vários canais de $2^{\mathrm{a}}$ e $3^{\mathrm{a}}$ ordem, difi- cultando a capacidade de vazão do arroio.

A classe de suscetibilidade muito forte corresponde predominantemente às áreas de menores altitudes da bacia hidrográfica, constantemente inundadas. Em todas as imagens de satélite essas áreas aparecem submersas, evidenciando que chuvas acumuladas acima de $118 \mathrm{~mm}$ são suficientes para inundar estes setores. Na bacia do arroio Santa Isabel três setores foram enquadrados nesta classe de suscetibilidade, associados a diferentes condicionantes. O primeiro setor localiza-se no segmento do arroio Santa Isabel, a montante de uma barragem (Figura 9D). Esta área caracteriza-se pela presença de solos hidromórficos, mal drenados, e relevo rebaixado em relação aos terraços colúvioaluvionares adjacentes. Esta área sofre influência do controle de vazão da barragem, responsável pela retenção do volume excedente de água em eventos de precipitação. O segundo setor localiza-se em uma curva acentuada do arroio Santa Isabel, a jusante do primeiro setor, onde a planície de inundação encontra-se rebaixada e confinada pelo terraço lagunar (Figura 9F) e pelo relevo colinoso. O relevo no entorno do canal, muito plano favorece os eventos de inundação. O terceiro setor consiste 
de uma faixa extensa ao longo do arroio Santa Isabel, próxima a sua foz, que apresenta as menores altitudes da bacia e é constituída por Neossolos e Planossolos. Os trabalhos de campo e as imagens de satélite (Figura 5) permitiram constatar que esta área sofre influência do rio Camaquã, quando ocorre extravasamento deste, provocando inundações, e também devido ao barramento da vazão da bacia do arroio Santa Isabel.

\section{CONCLUSÕES}

O mapeamento da suscetibilidade à inundação da bacia hidrográfica do arroio Santa Isabel permitiu identificar os fatores naturais e antrópicos, responsáveis pela ocorrência desse processo. Para a definição das diferentes classes de suscetibilidade, destacam-se os seguintes fatores: amplitude do relevo e declividade na planície de inundação e no seu entorno imediato, confluência de corpos hídricos e a ação antrópica (construção de barragens e supressão de vegetação nativa). A influência exercida pelo rio Camaquã em inundações próximas a foz do arroio Santa Isabel é uma variável externa, que também condiciona os eventos de inundações na área.

A suscetibilidade varia de média a muito forte em aproximadamente $75 \%$ do sistema fluvial, fato que evidencia a importância deste estudo no planejamento estratégico de uso da área. Destaca-se, ainda, a alta frequência de eventos de chuva na série histórica, tanto aqueles acumulados (166), como os extremos (253), que possuem alto potencial de indução de inundação, associado às características intrínsecas da bacia.

A metodologia adotada e os procedimentos aplicados neste mapeamento foram balizadas com observações feitas nos trabalhos de campo e registros de inundações em imagens de satélite. Salienta-se a importância de análises futuras considerando a vazão dos arroios para que possa ser definido o limiar de chuva para as inundações na bacia. Este mapeamento pode servir de base para um futuro ordenamento territorial e até mesmo de referência para análises em bacias hidrográficas da região costeira do Rio Grande do Sul, pois utiliza dados acessíveis e que permitem uma análise integrada.

\section{AGRADECIMENTOS}

Ao Programa de Pós-Graduação em Geografia da UFRGS pelo suporte no desenvolvimento da pesquisa, à Coordenação de Aperfeiçoamento de Pessoal de Nível Superior (CAPES) e à Fundação de Amparo à Pesquisa do estado do Rio Grande do
Sul (FAPERGS) pelo aporte financeiro e aos revisores anônimos da Revista do Instituto Geológico pelas sugestões apresentadas.

\section{REFERÊNCIAS BIBLIOGRÁFICAS}

AMARAL, R.; RIBEIRO, R.R. 2009. Inundação e Enchentes. In: L.K. Tominaga, J. Santoro, R. Amaral (Org.) Desastres Naturais: Conhecer para prevenir. São Paulo, Instituto Geológico, $1^{a}$ ed., p. 39-52.

BERLATO, M.A.; FONTANA, D.C. 2003. El Niño e La Niña: impactos no clima, na vegetação e na agricultura do Rio Grande do Sul; aplicações de previsões climáticas na agricultura. Editora UFRGS, Porto Alegre, 110 p.

CALVETTI, L.; BENETI, C.; GONÇALVES, J.E.; MOREIRA, I.A.; DUQUIA, C.; BREDA, A.; ALVES, T.A. 2006. Definição de classes de precipitação para utilização em previsões por categoria e hidrológica. In: SBMET, CONGRESSO BRASILEIRO DE METEOROLOGIA, 14, Florianópolis, Anais, 6 p.

CARGNIN, A.P.; BERTÊ, A.M.A.; KLARMANN, H.; PROFES, S.M.B.; OLIVEIRA, S.B. 2002. Atlas Sócio Econômico Rio Grande do Sul. Disponível em http://www.scp.rs.gov.br/ atlas/atlas.asp? menu=340. Acessado em 10 mar. 2012.

CASTRO, A.L.C. 1998. Glossário de defesa civil, estudos de risco e medicina de desastres. Ministério do Planejamento e Orçamento, Brasília, $2^{\mathrm{a}}$ ed., 283 p.

COLLINS, T. Disaster risk for floods: 1980 - 2000. 2004. United Nations University, Tokyo. Disponível em http://unu.edu/news/ehs/ floods.doc. Acessado em 15 dez. 2010.

COOKE, R.U.; DOORNKAMP J.C. 1990. Drainage basins and sediment transfer. In: R. U. Cooke, J.C. Doornkamp (Org.) Geomorphology in environmental management. A new introduction. New York, Clarendon Press, $2^{\mathrm{a}}$ ed., 409 p.

CPRM - COMPANHIA DE PESQUISA DE RECURSOS MINERAIS. 2003. Geologia, Tectônica e Recursos Minerais do Brasil: texto, mapas e SIG. CPRM, Brasília, 674 p., DVD anexo. 
EMBRAPA - EMPRESA BRASILEIRA DE PESQUISAS AGROPECUÁRIAS. 2006. Estudo de solos do município de Cristal - RS. Ministério da Agricultura, Pecuária e Abastecimento, Pelotas, 50 p. (Circular Técnica, 53).

IBGE - INSTITUTO BRASILEIRO DE GEOGRAFIA E ESTATÍSTICA. 1986. Folha SH. 22 Porto Alegre e parte das folhas SH. 21 Uruguaiana e SI. 22 Lagoa Mirim. Levantamento dos recursos naturais: geologia, geomorfologia, pedologia, vegetação e uso potencial da terra. IBGE, Rio de Janeiro, 791 p.

IBGE - INSTITUTO BRASILEIRO DE GEOGRAFIA E ESTATÍSTICA. 2003. Mapa Geomorfológico das Folhas Pelotas e Mostarda - SH. 22-Y-D/Z-C, escala 1:250.000. Diretoria de Geociências - DGC, Rio Grande do Sul.

\section{IBGE - INSTITUTO BRASILEIRO DE GEO-} GRAFIA E ESTATÍSTICA. 2006. Manual técnico de uso da terra. IBGE, Rio de Janeiro, $\mathrm{n}^{\mathrm{o}} 7,2^{\mathrm{a}}$ ed.

LIEBMANN, B.; JONES, C.; CARVALHO, L.D. 2001. Interannual variability of daily extreme precipitation events in the state of São Paulo, Brazil. Journal of climate, 14(2): 208-218.

LIMA, L.M.M. 2010. Mapeamento da suscetibilidade à inundação na bacia hidrográfica do Arroio do Salso, Porto Alegre - RS. Programa de Pós-graduação em Geografia, Universidade Federal do Rio Grande do Sul, Porto Alegre, Dissertação de Mestrado, 174 p.

MIRANDA, E.E. (Coord.). 2005. Brasil em Relevo. Campinas, Embrapa Monitoramento por
Satélite. Disponível em http://www.relevobr. cnpm.embrapa.br. Acessado em 20 jan. 2010.

MORISAWA, M.E. 1962. Quantitative Geomorphology of Some Watersheds in the Appalachian Plateau. Geological Society of America bulletin, 73: 1025-1046.

ROSS, J.L.S. 1992. O registro cartográfico dos fatos geomorfológicos e a questão da taxonomia do relevo. Revista do Departamento de Geografia, 6: 17-29.

SANTOS, K.R. 2012. Inundações urbanas: um passeio pela literatura. Elisée - Revista de Geografia da UEG, 1(1): 177-190.

SOUZA, C.R.G. 1998. Flooding in the São Sebastião region, northern coast of São Paulo State, Brazil. Anais da Academia Brasileira de Ciências, 70(2): 354-366.

SOUZA, C.R.G. 2005. Suscetibilidade morfométrica de bacias de drenagem ao desenvolvimento de inundações em áreas costeira. Revista Brasileira de Geomorfologia, 6(1): 45-61.

TELLES, R.M. 2002. Inundações urbanas nos municípios de Pedro Osório e Cerrito - RS. Programa de Pós-graduação em Geografia, Universidade Federal do Rio Grande do Sul, Porto Alegre, Dissertação de Mestrado, 74 p.

TOMAZELLI, L.J.; VILLWOCK, J.A. 2005. Mapeamento geológico de planícies costeiras: o exemplo da costa do Rio Grande do Sul. Gravel, 3: 109-115.

TUCCI, C.E.M. 2002. Hidrologia: ciência e aplicação. Editora da UFRGS, Porto Alegre, $3^{\mathrm{a}}$ ed., $943 \mathrm{p}$.

\section{Endereço dos autores:}

Jonathan Duarte Marth, Nina Simone Vilaverde Moura e Edinei Koester - Instituto de Geociências, Universidade Federal do Rio Grande do Sul, Av. Bento Gonçalves, 9500, Campus do Vale, Porto Alegre, Rio Grande do Sul.E-mails: jonathan.ufpel@yahoo.com.br, nina.moura@ufrgs.br, edneikoester@yahoo. com.br

Artigo submetido em 30 de março de 2016, aceito em 13 de junho de 2016. 